\title{
Synthesis, Characterization, and Antioxidant Activity of Some 2-Methoxyphenols derivatives
}

https://doi.org/10.1515/hc-2020-0112

Received June 17, 2020; accepted July 27, 2020.

Abstract: Oxidative stress is a causative factor in the pathophysiology of numerous diseases, such as diabetes, atherosclerosis, cancer, and neurodegenerative and cardiovascular diseases. Therapeutic antioxidants are promising candidates for preventing and treating conditions in which oxidative stress is a contributing factor. In this study, we report the design, synthesis and antioxidant activity of six compounds containing the 2-methoxyphenol moiety core structure. The synthesized derivatives were characterized using ${ }^{1} \mathrm{H}$ NMR, ${ }^{13} \mathrm{C}$ NMR, Fourier-transform infrared (FT-IR), and elemental analysis spectroscopy. The antioxidant properties of the compounds were evaluated using the 2,2-diphenyl-1-picryl-hydrazyl-hydrate (DPPH), 2,2'-azino-bis(3-ethylbenzothiazoline-6-sulfonic acid (ABTS), and oxygen radical absorbance capacity (ORAC) assay. New phenolic acid-derived compounds with antioxidant activity were identified.

Keywords: phenol, antioxidant, antiradical, ferulic acid, curcumin

\section{Introduction}

Free radicals are atoms, molecules or ions that possess an unpaired electron in orbit [1]. They are continually formed in the body and can become toxic when obtained in high concentration or in the presence of a deficiency

\footnotetext{
*Corresponding author: Shaikha S. AlNeyadi, Department of Chemistry, College of Science, UAE University Al-Ain, 15551 UAE E-mail: shaikha.alneyadi@uaeu.ac.ae; Tel.:+971501099154 Tony G. Thomas, Ruba Al Ajeil and N Munawar, Department of Chemistry, College of Science, UAE University Al-Ain, 15551 UAE Naheed Amer, Department of Pharmacology, College of Health and Science, UAE University Al-Ain, 17666 UAE Priya Breitener, General Requirement Department, Fathima College of Health Science, Abu Dhabi
}

in the natural antioxidant defenses. At high concentration free radicals can damage lipids, proteins, and DNA within cells and tissues. The human body does have essential defense pathways to counter free radicals in the form of enzymes such as superoxide dismutase, catalase, and glutathione peroxidase. However, the unbalances between the formation and detoxification of free radical species results in the development of oxidative stress. This leads to the development of severe diseases, such as cancer, atherosclerosis, aging, immunosuppression, inflammation, ischemic heart disease, diabetes, and neurodegenerative disorders [2]. Antioxidants are compounds that can interact with free radicals in a safe way, terminate the reaction, and convert them to a harmless molecule by offering an electron. Antioxidants therefore reduce the oxidative stress and thus protecting the cells from oxidative damage [3].

Eugenol and isoeugenol are examples of natural methoxyphenols used in perfumes, detergents, air fresheners and cosmetics (Figure 1). Eugenol is used also as a part of zinc-oxide eugenol cement in dentistry, and has demonstrated effective antioxidant activity [4]. In addition, Eugenol prevents themetal-mediated low density lipoprotein (LDL) oxidation acting as a physiological antioxidant in vivo and apocynin is an efficient inhibitor of the nicotinamide adenine dinucleotide phosphate (NADPH) oxidase complex [5]. The antioxidant properties of other natural phenols such as eugenol, creosol, apocynin and isoeugenol, have already been reported [6].

The design of new antioxidant compounds has become an important therapeutic matter given the wide-ranging damage to cellular macromolecules caused by reactive oxygen species (ROS). Therefore, extensive research has been focused to identify new antioxidants to prevent radical-induced damage. In this study, we concentrated on design, synthesis, characterization, and evaluation of the antioxidant activity of newly methoxyphenol derivatives. The structures of the various synthesized compounds were verified based on elemental analysis, along with infrared (IR) and 1D-NMR spectral data. 


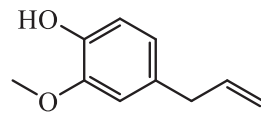

eugenol

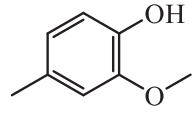

creosol

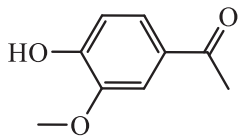

apocynin

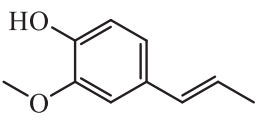

isoeugenol

Figure 1 Structures of some natural phenols

\section{Materials and Methods}

\section{General}

All chemicals and reagents were obtained from SigmaAldrich Chemical Company (Sigma Aldrich Chemical Company, street. Louis, MO, USA) and used without additional purification. Thin-layer chromatography was performed on silica gel coated with fluorescent indicator $\mathrm{F}_{254}$ plates purchase from Fluka Company. Column chromatography was implemented on Silica gel S, 0.063$0.1 \mathrm{~mm}$. Melting points were determined on a Gallenkamp melting point apparatus and were uncorrected. IR spectra were measured using $\mathrm{KBr}$ pellets on a Thermo Nicolet model 470 Fourier-transform spectrophotometer. Nuclear magnetic resonance $\left({ }^{1} \mathrm{H}\right.$ and ${ }^{13} \mathrm{C}$ spectra) were recorded on a Varian $400 \mathrm{MHz}$ spectrophotometer. Chemical shifts were expressed in part per million $(\delta)$ with tetramethylsilane (TMS) as an internal standard. Elemental analysis was conducted using a Leco CHN-600 elemental analyzer.

\section{Synthesis of methoxyphenol derivatives}

\section{5-(4-Hydroxy-3-methoxybenzyl)-2,2-dimethyl-1,3- dioxane-4,6-dione (4)}

4-Hydroxy-3-methoxybenzaldehyde 2 (1.5 g, $10.0 \mathrm{mmol}$ ) was dissolved in 2-propanol and acetic acid (0.1 equiv). Then,2,2-dimethyl-1,3-dioxane-4,6-dione1(1.5g,10.5mmol) was added. Then the reaction was heated to $75^{\circ} \mathrm{C}$ for $2 \mathrm{~h}$. The solvent was removed under reduced pressure. The residue was washed 2-3 times with aqueous $\mathrm{NaHSO}_{3}$ solution $(20 \% \mathrm{w} / \mathrm{v})$, water and hexane to obtain compound 3 in $70 \%$ and $1.9 \mathrm{~g}$. Compound 3 was dissolved in dichloromethane $(100 \mathrm{~mL})$ and the solution was cooled in an ice bath, then acetic acid (31.0 equiv) was added. After 15 min, $\mathrm{NaBH}_{4}$ (8.0 equiv) was added within $1 \mathrm{~h}$. The reaction was removed from the ice bath and kept at room temperature at $25^{\circ} \mathrm{C}$ for $1 \mathrm{~h}$. After discoloration, the reaction mixture was diluted with $100 \mathrm{~mL}$ water and extracted three times with $50 \mathrm{~mL}$ with dichloromethane. The organic layers were collective and washed two times with water. The organic layer was dried over $\mathrm{MgSO}_{4}$, and the solvent was evaporated in vacuum, yielding compound 4 after recrystallization from hot ethyl acetate-hexanes. This compound was white powder; yield, $63 \%$ and $1.76 \mathrm{~g}$; mp, $130{ }^{\circ} \mathrm{C}$; IR (KBr, cm$\left.{ }^{-1}\right): 3518$ (-OH), 2874 (C-H aliphatic), 1793, $1755(\mathrm{C}=\mathrm{O})$; ${ }^{1} \mathrm{H}-\mathrm{NMR}$ [CDCl, $\left.400 \mathrm{MHz}\right]:(\delta, \mathrm{ppm}) 6.85$ (brs, $1 \mathrm{H}$, aromatic $\mathrm{H}$ ), 6.81-6.68 (m, $2 \mathrm{H}$, aromatic $\mathrm{H}$ ), 5.53 (brs, $1 \mathrm{H}, \mathrm{OH}$, exchanges with $\mathrm{D}_{2} \mathrm{O}$ ), $3.85\left(\mathrm{~s}, 3 \mathrm{H}, \mathrm{OCH}_{3}\right.$ ), 3.66 (t, $J=4.9 \mathrm{~Hz}, 1 \mathrm{H}, \mathrm{CH}), 3.42\left(\mathrm{~d}, J=4.9 \mathrm{~Hz}, 2 \mathrm{H}, \mathrm{CH}_{2}\right), 1.72$ $\left(\mathrm{s}, 6 \mathrm{H}, \mathrm{CH}_{3}\right) ;{ }^{13} \mathrm{C}-\mathrm{NMR}\left[\mathrm{CDCl}_{3}, 100 \mathrm{MHz}\right]:(\delta, \mathrm{ppm})$ 165.5, 147.7, 144.9, 128.8, 120.8, 115.6, 113.0, 105.2, 55.9, 46.3, 31.1, 26.5; Anal. Calcd for $\mathrm{C}_{14} \mathrm{H}_{16} \mathrm{O}_{6}$ (280.28): C, 60.00; H, 5.75; Found: 59.97; H, 5.69.

\section{3-(4-Hydroxy-3-methoxyphenyl)propanoic acid (7)}

To a solution of 4-hydroxy-3-methoxybenzaldehyde $\mathbf{1}$ (1 mmol) and malonic acid $5(1.2 \mathrm{mmol})$ in pyridine $(2.5 \mathrm{~mL} / \mathrm{mmol})$, piperidine $(0.04 \mathrm{mmol})$ was added at $120{ }^{\circ} \mathrm{C}$, and the reaction mixture was heated under reflux for $4 \mathrm{~h}$. The solvent was removed in vacuo as an azeotrope with toluene $(3 \times 70 \mathrm{~mL})$. Water $(100 \mathrm{~mL})$ was added, and the aqueous phase was extracted with ethyl acetate $(3 \times 100 \mathrm{~mL})$ and ethanol $(1 \times 100 \mathrm{~mL})$, dried over $\mathrm{MgSO}_{4}$, and concentrated to obtain 6 in $74 \%$ and $0.14 \mathrm{~g}$. Then, the catalyst, $10 \% \mathrm{Pd} / \mathrm{C}(0.014 \mathrm{~g})$, was added to a solution of $6(0.194 \mathrm{~g}, 1 \mathrm{mmol})$ in degassed ethyl acetate $(100 \mathrm{~mL})$. The reaction mixture was stirred at room temperature overnight under $\mathrm{H}_{2}$ atmosphere. After completion, the reaction mixture was filtered and concentrated to afford compound 7 ; yield $95 \%$ and $0.18 \mathrm{~g}$; mp, $92{ }^{\circ} \mathrm{C}$; IR ( $\left.\mathrm{KBr}, \mathrm{cm}^{-1}\right)$ : 3409 (-OH), 2938 (CH-aliphatic), $1708(\mathrm{C}=\mathrm{O})$, $1605(\mathrm{C}=\mathrm{C})$; ${ }^{1} \mathrm{H}-\mathrm{NMR}\left[\mathrm{CDCl}_{3}, 400 \mathrm{MHz}\right]:(\delta, \mathrm{ppm}) 10.50$ (brs, $1 \mathrm{H}, \mathrm{CO}_{2} \mathrm{H}$, exchanges with $\left.\mathrm{D}_{2} \mathrm{O}\right), 6.87(\mathrm{~d}, \mathrm{~J}=8.0 \mathrm{~Hz}, 1 \mathrm{H})$, 6.73 (brs, 1H), 6.71 (d, J = 8.0 Hz, 1H), 5.60 (brs, 1H, OH, exchanges with $\left.\mathrm{D}_{2} \mathrm{O}\right), 3.88\left(\mathrm{~s}, 3 \mathrm{H}, \mathrm{OCH}_{3}\right), 2.90(\mathrm{t}, J=7.8 \mathrm{~Hz}$, 2H), 2.70 (t, $J=7.8 \mathrm{~Hz}, 2 \mathrm{H}) ;{ }^{13} \mathrm{C}-\mathrm{NMR}\left[\mathrm{CDCl}_{3}, 100 \mathrm{MHz}\right]$ : $(\delta, \mathrm{ppm}) 179.2,146.4,144.1,132.0,120.8,114.4,110.9,55.8$, $36.0,30.3$.

\section{3-(4-Hydroxy-3-methoxyphenyl)-1-(piperidin-1-yl) propan-1-one (8)}

$N, N$-Carbonyldiimidazole $(0.545 \mathrm{~g}, 3.36 \mathrm{mmol})$ was added to a solution of 3-(4-hydroxy-3-methoxyphenyl) propanoic 
acid 7 (0.6 g, $3.06 \mathrm{mmol})$ in $10 \mathrm{~mL}$ of dry THF. After 30 min, piperidine $(0.302 \mathrm{~mL}, 3.06 \mathrm{mmol})$ was added and the mixture was stirred overnight. The precipitate formed then was washed with dichloromethane to obtain $\mathbf{8}$. White solid; yield $60 \%$ and $0.48 \mathrm{~g} ; \mathrm{mp} 120^{\circ} \mathrm{C}$; IR $\left(\mathrm{KBr}, \mathrm{cm}^{-1}\right): 3392$ (-OH), 3010 (C-H aromatic), 1749 (C=O); ${ }^{1} \mathrm{H}-\mathrm{NMR}$ [DMSO$\left.d_{6}, 400 \mathrm{MHz}\right]:(\delta, \mathrm{ppm}) 8.68$ (brs, $1 \mathrm{H}, \mathrm{OH}$, exchanges with $\left.\mathrm{D}_{2} \mathrm{O}\right), 6.77(\mathrm{~d}, J=1.9 \mathrm{~Hz}, 1 \mathrm{H}$, aromatic $\mathrm{H}), 6.64(\mathrm{~d}, J=8.0 \mathrm{~Hz}$, $1 \mathrm{H}), 6.59(\mathrm{dd}, J=8.0,2.0 \mathrm{~Hz}, 1 \mathrm{H}), 3.72\left(\mathrm{~s}, 3 \mathrm{H}, \mathrm{OCH}_{3}\right), 3.31-$ $3.35\left(\mathrm{~m}, 4 \mathrm{H}, \mathrm{CH}_{2}\right.$ piperidine), $2.67\left(\mathrm{~m}, 2 \mathrm{H}, \mathrm{CH}_{2}\right), 2.51-2.53$ (m, $2 \mathrm{H}, \mathrm{CH}_{2}$ ), 1.36-1.53 (m, 6H, $\mathrm{CH}_{2}$ piperidine); ${ }^{13} \mathrm{C}-\mathrm{NMR}$ [DMSO- $d_{6}, 100 \mathrm{MHz}$ ]: $(\delta, \mathrm{ppm}) 170.1,147.7,144.9,132.6$, 120.8, 115.6, 113.0, 55.9, 46.3, 34.8, 31.1, 26.5, 24.5; Anal. Calcd for $\mathrm{C}_{15} \mathrm{H}_{21} \mathrm{NO}_{3}$ (263.34): C, 68.42; $\mathrm{H}, 8.04 ; \mathrm{N}, 5.32$; Found: C, 68.39; H, 7.98; N, 5.27.

\section{(E)-1-(4-Chlorophenyl)-3-(4-hydroxy-3-methoxyphenyl) prop-2-en-1-one (10)}

4-Hydroxy-3-methoxybenzaldehyde 1 ( $1 \mathrm{~g}, 6.57 \mathrm{mmol})$ and 1-(4-chlorophenyl)ethenone $9(852 \mu \mathrm{L}, 6.57 \mathrm{mmol})$ were mixed and stirred in $10 \mathrm{~mL}$ of methanol for 5-10 min; then $\mathrm{H}_{2} \mathrm{SO}_{4}(98 \%, 3.75 \mathrm{mmol})$ was added and the reaction was heated to $80{ }^{\circ} \mathrm{C}$ for $48 \mathrm{~h}$. After completion, the solution was neutralized by adding a $\mathrm{NaOH}$ solution $(20 \% \mathrm{w} / \mathrm{v})$. The solution then extracted with ethyl acetate after diluted with water. The organic layer was dried over $\mathrm{Na}_{2} \mathrm{SO}_{4}$ and the ethyl acetate was evaporated. The crude product was purified using silica gel flash chromatography to yield compound 10; yield, $48 \%$ and $0.14 \mathrm{~g}$; $\mathrm{mp}, 218{ }^{\circ} \mathrm{C}$; IR (KBr, cm-1): 3430 (-OH), 3093 (C-H aromatic), 2954 (C-Haliphatic), $1651(\mathrm{C}=\mathrm{O}), 1563(\mathrm{C}=\mathrm{C}), 1522$ ( $\mathrm{C}=$ Caromatic); ${ }^{1} \mathrm{H}-\mathrm{NMR}$ [DMSO- $d_{6}, 400 \mathrm{MHz}$ ]: $(\delta, \mathrm{ppm}) 10.31$ (brs, $1 \mathrm{H}, \mathrm{OH}$, exchanges with D2O), $7.79-7.77$ (m, 2H, aromatic H), 7.57 $(\mathrm{d}, \mathrm{d}, 1 \mathrm{H}, \mathrm{COCH}=\mathrm{CH}, J=15 \mathrm{~Hz}), 7.52-7.50(\mathrm{~m}, 2 \mathrm{H}$, aromatic $\mathrm{H})$, $7.11-6.97(\mathrm{~m}, 3 \mathrm{H}$, aromatic $\mathrm{H}), 6.14(\mathrm{~d}, 1 \mathrm{H}, \mathrm{COCH}=\mathrm{CH}$, $J=15 \mathrm{~Hz}), 3.67\left(\mathrm{~s}, 3 \mathrm{H}, \mathrm{OCH}_{3}\right) ;{ }^{13} \mathrm{C}-\mathrm{NMR}$ [DMSO-d, 100 MHz]: ( $\delta, \mathrm{ppm}) 185.4,151.8,150.6,148.1,145.6,143.6,139.1$, 135.3, 129.9, 128.7, 118.7, 114.8, 107.6, 55.2; Anal. Calcd for $\mathrm{C}_{16} \mathrm{H}_{13} \mathrm{ClO}_{3}$ (288.73): C, 66.56; H, 4.54; Found: C, 66.53; H, 4.48 .

\section{(2E,6E)-2,6-bis(4-Hydroxy-3-methoxybenzylidene) cyclohexanone (12)}

4-Hydroxy-3-methoxybenzaldehyde 1 (1.9 g, $12.5 \mathrm{mmol})$ and cyclohexanone $\mathbf{1 1}(0.65 \mathrm{~mL}, 6.25 \mathrm{mmol})$ were mixed and stirred at room temperature for $5 \mathrm{~min}$. Then, conc. hydrochloric acid $(4 \mathrm{~mL})$ was added slowly, followed by stirring for $3 \mathrm{~h}$. Cold water was added to the mixture, filtered and dried in vacuum. The product was recrystallized from ethanol to obtain compound 12; yield $70 \%$ and $3.2 \mathrm{~g}$; mp, $182{ }^{\circ} \mathrm{C}$; IR ( $\left.\mathrm{KBr}, \mathrm{cm}^{-1}\right): 3368$ (-OH), 3045 (C-H aromatic), 2988 (C-H aliphatic), 1639 (C=O), 1577 (C=C), 1515 (C=C aromatic); ${ }^{1} \mathrm{H}-\mathrm{NMR}\left[\mathrm{CDCl}_{3}, 400 \mathrm{MHz}\right]:(\delta, \mathrm{ppm}) 9.83$ (brs, $2 \mathrm{H}, \mathrm{OH}$, exchanges with $\left.\mathrm{D}_{2} \mathrm{O}\right), 7.74(\mathrm{~s}, 2 \mathrm{H}$, vinylic $\mathrm{H})$, 7.09-6.93 ( m, 6H, aromatic $\mathrm{H}), 3.92\left(\mathrm{~s}, 6 \mathrm{H}, \mathrm{OCH}_{3}\right), 2.95-2.95$ (m, 4H, $\left.\mathrm{CH}_{2}\right), 1.84-1.78\left(\mathrm{~m}, 2 \mathrm{H}, \mathrm{CH}_{2}\right) ;{ }^{13} \mathrm{C}-\mathrm{NMR}\left[\mathrm{CDCl}_{3}, 100\right.$ $\mathrm{MHz}$ : ( $\delta$, ppm) 190.1, 146.4, 137.0, 134.4, 128.5, 124.4, 114.4, 113.2, 55.9, 28.5, 23.0; Anal. Calcd for $\mathrm{C}_{22} \mathrm{H}_{22} \mathrm{O}_{5}$ (366.41): C, 72.12; H, 6.05; Found: C, 72.09; H, 5.99.

\section{(E)-4-(4-Hydroxy-3-methoxyphenyl)but-3-en- 2-one (13)}

4-hydroxy-3-methoxybenzaldehyde 1 (3.04 g, $0.020 \mathrm{~mol}$ ) was dissolved in $12 \mathrm{~mL}$ of acetone under stirring at room temperature. Then, $10 \%$ aqueous $\mathrm{NaOH}(9 \mathrm{~mL})$ was added and allowed to stand for $48 \mathrm{~h}$. Distilled water $(50 \mathrm{~mL})$ was added. Then, $10 \%$ aqueous $\mathrm{HCl}(15 \mathrm{~mL})$ was added. The yellow precipitate formed was filtered, dried and recrystallized from ethanol/water to yield compound $\mathbf{1 3 .}$ This compound was yellow powder; yield $70 \%$ and $2.7 \mathrm{~g}$; $\mathrm{mp} 126^{\circ} \mathrm{C}$; IR ( $\left.\mathrm{KBr}, \mathrm{cm}^{-1}\right)$ : 3285 (-OH), 3001 (C-H aromatic), 2849 (C-H aliphatic), 1675 (C=O), 1638 (C=C); ${ }^{1} \mathrm{H}-\mathrm{NMR}$ [CDCl, $400 \mathrm{MHz}]:(\delta, \mathrm{ppm}) 7.43-7.47(\mathrm{~d}, J=16.2 \mathrm{~Hz}$, olefinic $\mathrm{H}), 7.06-7.11(\mathrm{~m}, 2 \mathrm{H}$, aromatic $\mathrm{H}), 6.93-6.95(\mathrm{~d}, J=8 \mathrm{~Hz}$, $1 \mathrm{H}$, aromatic $\mathrm{H}), 6.57-6.61(\mathrm{~d}, J=16.2 \mathrm{~Hz}$, olefinic $\mathrm{H}), 5.91$ (s, $1 \mathrm{H}, \mathrm{OH}$, exchanges with $\left.\mathrm{D}_{2} \mathrm{O}\right), 3.94\left(\mathrm{~s}, 3 \mathrm{H}, \mathrm{OCH}_{3}\right), 2.37$ (s, 3H, $\left.\mathrm{CH}_{3}\right) ;{ }^{13} \mathrm{C}-\mathrm{NMR}\left[\mathrm{CDCl}_{3}, 100 \mathrm{MHz}\right.$ ]: $(\delta, \mathrm{ppm})$ 198.5, 148.2, 146.9, 143.8, 127.0, 125.0, 123.5, 114.8, 109.2, 55.9, 27.5; Anal. Calcd for $\mathrm{C}_{11} \mathrm{H}_{12} \mathrm{O}_{3}$ (192.21): C, 68.74; H, 6.29; Found: C, 68.71; H, 6.23.

\section{(1E,4E)-1-(4-Hydroxy-3-methoxyphenyl)-5- (4-hydroxyphenyl)penta-1,4-dien-3-one (15)}

Compound $9(0.5 \mathrm{~g}, 2.60 \mathrm{mmol})$ and 4-hydroxybenzaldehyde $14(0.32 \mathrm{~g}, 2.60 \mathrm{mmol})$ were mixed in $10 \mathrm{~mL}$ ethanol for $5 \mathrm{~min}$. Then, concentrated $\mathrm{HCl}(0.5 \mathrm{~mL})$ was added, followed by stirring overnight. The mixture was treated with cold water, filtered and dried in a vacuum. Compound 15 was obtained after recrystallized from an ethanol- $\mathrm{H}_{2} \mathrm{O}$ mixture; yield $52 \%$ and $0.4 \mathrm{~g}$; $\mathrm{mp}, 176^{\circ} \mathrm{C}$; IR, $\left(\mathrm{KBr}, \mathrm{cm}^{-1}\right)$ : 3585 (-OH), 3069 (C-H aromatic), 2955 (C-H aliphatic), 1697 $(\mathrm{C}=0), 1593(\mathrm{C}=\mathrm{C}), 1513$ ( $\mathrm{C}=\mathrm{C}$ aromatic); ${ }^{1} \mathrm{H}-\mathrm{NMR}$ [DMSO- $d_{\sigma}$, $400 \mathrm{MHz}$ : $(\delta, \mathrm{ppm}) 10.03$ (brs, $1 \mathrm{H}, \mathrm{OH}$, exchanges with $\mathrm{D}_{2} \mathrm{O}$ ), 9.68 (brs, $1 \mathrm{H}, \mathrm{OH}$, exchanges with $\left.\mathrm{D}_{2} \mathrm{O}\right), 7.65-7.66(\mathrm{~d}, J=15$ 
$\mathrm{Hz}$, ,2H, olefinic- $\mathrm{H})$, 7.60-7.62 (m, 2H, aromatic $\mathrm{H})$, 7.34-7.35 (d, $J=15 \mathrm{~Hz}, 2 \mathrm{H}$, olefinic- $\mathrm{H}), 7.08-7.19(\mathrm{~m}, 3 \mathrm{H}$, aromatic $\mathrm{H})$, 6.81-6.82 (m, 2H, aromatic $\mathrm{H}), 3.82\left(\mathrm{~s}, 3 \mathrm{H}, \mathrm{OCH}_{3}\right) ;{ }^{13} \mathrm{C}-\mathrm{NMR}$ [DMSO- $\left.d_{6}, 100 \mathrm{MHz}\right]:(\delta, \mathrm{ppm}) 188.5,160.3,149.8,148.3$, $143.3,142.8,130.9,126.7,126.3,123.7,123.4,122.9,116.3$, 116.1, 111.7, 56.1; Anal. Calcd for $\mathrm{C}_{18} \mathrm{H}_{16} \mathrm{O}_{4}$ (296.32): C, 72.96; H, 5.44; Found: C, 72.93; H, 5.39.

\section{(1E,4E)-1-(4-Fluorophenyl)-5-(4-hydroxy-3- methoxyphenyl)penta-1,4-dien-3-one (17)}

4-fluorobenzaldehyde 16 (0.23 g, $2.60 \mathrm{mmol})$ was mixed with (E)-4-(4-Hydroxy-3-methoxyphenyl)but-3-en-2-one $9(0.5 \mathrm{~g}, 2.60 \mathrm{mmol})$ in $10 \mathrm{~mL}$ ethanol for $5 \mathrm{~min}$. Then, $2 \mathrm{M} \mathrm{NaOH}(10 \mathrm{~mL})$ was added and stirred overnight. The resulting mixture was acidified by concentrated $\mathrm{HCl}$, and the residue was washed with cold water and dried in air. The product was recrystallized from an ethanol/water mixture to obtain 17; yield, $73 \%$ and $0.57 \mathrm{~g}$; mp, $210{ }^{\circ} \mathrm{C}$; IR (KBr, cm-1 ): 3427 (-OH), 3001 (C-H aromatic), 2926 (C-H aliphatic), $1674(\mathrm{C}=\mathrm{O}), 1618(\mathrm{C}=\mathrm{C}), 1577$ ( $\mathrm{C}=\mathrm{C}$ aromatic); ${ }^{1} \mathrm{H}-\mathrm{NMR}$ [DMSO- $d_{6}, 400 \mathrm{MHz}$ ]: $(\delta, \mathrm{ppm}) 9.87$ (brs, $1 \mathrm{H}, \mathrm{OH}$, exchanges with $\left.\mathrm{D}_{2} \mathrm{O}\right), 7.91-7.95(\mathrm{~d}, 2 \mathrm{H}, J=15 \mathrm{~Hz}$ olefinic $\mathrm{H})$, 7.72 (brs, $1 \mathrm{H}$, aromatic $\mathrm{H}$ ), 7.65 (m, 2H, aromatic $\mathrm{H}$ ), 7.36 (d, $2 \mathrm{H}, J=15 \mathrm{~Hz}$ olefinic $\mathrm{H}), 7.09$ (m, 2H, aromatic $\mathrm{H}$ ), $6.65(\mathrm{~m}, 1 \mathrm{H}$, aromatic $\mathrm{H}), 6.63(\mathrm{~m}, 1 \mathrm{H}$, aromatic $\mathrm{H}), 3.70$ $\left(\mathrm{s}, 3 \mathrm{H}, \mathrm{OCH}_{3}\right) ;{ }^{13} \mathrm{C}-\mathrm{NMR}$ [DMSO- $\left.d_{6}, 100 \mathrm{MHz}\right]:(\delta, \mathrm{ppm}) 177.2$, 150.9, 150.7, 144.5, 143.3, 134.3, 133.7, 121.1 , 120.8, 120.1, 120.2, 119.5, 112.4, 112.3, 111.1, 65.1; Anal. Calcd for $\mathrm{C}_{18} \mathrm{H}_{15} \mathrm{FO}_{3}$ (298.31): C, 72.47; H, 5.07; Found: C, 72.44; H, 5.01.

\section{Antioxidant Activity}

Total Antioxidant Capacity Test Using the 2,2'-azinobis(3-ethylbenzothiazoline-6-sulfonic acid (ABTS) Kinetic Assay (Free-Radical-Scavenging Activity)

The total antioxidant capacity was obtained using the ABTS kinetic assay according to the manufacturer's instructions (Zenbio, Research Triangle Park, NC, USA). After diluting the myoglobin working solution with a dilution buffer, $10 \mu \mathrm{L}$ of $100 \mu \mathrm{M}$ of test compounds or Trolox standard or assay buffer were dispensed into a 96-well microplate. To start the reaction, $20 \mu \mathrm{L}$ of the myoglobin working solution and $100 \mu \mathrm{L}$ of the ABTS solution were added. The kinetic profile of ABTS+ scavenging by antioxidant compounds was monitored in a 96-well microplate using an Emax Plus microplate reader
(Molecular Devices, CA, USA). The ABTS assay measured the free-radical-scavenging activity of the compounds. Data are presented as mean \pm SEM and expressed as micromoles Trolox equivalent ( $\mu \mathrm{M} \mathrm{TE})$.

\section{Antioxidant Activity by Oxygen Radical Absorbance Capacity (ORAC) Assay}

The oxygen radical absorbance capacity of each test compound was determined using the ORAC Antioxidant Assay Kit (Zenbio, NC, USA) according to the manufacturer's instructions. Trolox standards were prepared in assay buffer $(0-100 \mu \mathrm{M})$, along with the test compounds $(100 \mu \mathrm{M})$. Fluorescein working solution $(150 \mu \mathrm{L})$ was added to the central wells of a 96-well black side, clear bottom plate, and mixed with $25 \mu \mathrm{L}$ of each of the standards or test compounds in triplicate; the plate was incubated at $37^{\circ} \mathrm{C}$ for at least $10 \mathrm{~min}$. The 2,2'-azobis(2amidinopropane) dihydrochloride [AAPH; sold as 2,2'-azobis(2-methylpropionamidine) dihydrochloride] working solution was added to each well $(25 \mu \mathrm{L})$ to initiate the reaction. The fluorescence was measured after 30 min incubation at $37^{\circ} \mathrm{C}$ using a multilabel plate reader (Perkin Elmer Victor3, USA) with excitation/ emission $=485 / 530 \mathrm{~nm}$. Presented as mean \pm SEM and expressed as micromoles Trolox equivalent ( $\mu \mathrm{M}$ TE). The ORAC values are presented as mean \pm SEM and expressed as $\mu \mathrm{M}$ TE.

\section{Antioxidant Activity by 2,2-diphenyl-1-picryl-hydrazyl- hydrate (DPPH) Assay}

The free radical scavenging ability of the test compounds was studied using the DPPH assay [7]. The test compounds in ethanol were prepared separately and added to the ethanol solution containing DPPH $(0.01 \mathrm{mmol})$ within the range of $5-50 \mu \mathrm{L}$ and adjusted to a final volume of $3 \mathrm{~mL}$ using ethanol as solvent. The scavenging ability of the test compounds was monitored spectrophotometrically by measuring the absorbance at $517 \mathrm{~nm}$ after $20 \mathrm{~min}$. The $\%$ inhibition was obtained using equation (1).

$$
\% \text { Inhibition }=\left\{\frac{\mathrm{ABS} \text { control }-\mathrm{ABS} \text { sample }}{\mathrm{ABS} \text { control }}\right\} * 100
$$

The $50 \%$ decline in absorbance of the DPPH solution was derived from the graph with the concentration $(\mu \mathrm{M})$ plotted against the absorbance. These concentration values were used to determine the $\mathrm{IC}_{50}$ values in $\mu \mathrm{M}$. 


\section{Results and Discussion}

\section{Synthesis}

Methoxyphenol derivatives have demonstrated extensive therapeutic effects; most of which depend on its antioxidant properties [8]. There have been recent efforts to maximize the therapeutic value of Methoxyphenol by creating structurally modified derivatives with potentially enhanced physicochemical, antioxidant, and therapeutic properties. In this study, we synthesized the six different methoxyphenol derivatives for antioxidant activity measurements. The first compound 5-(4-hydroxy-3-methoxybenzyl)-2,2-dimethyl-1,3dioxane-4,6-dione 4, was obtained by condensation of 2,2-dimethyl-1,3-dioxane-4,6-dione(Meldrum's acid) 1 with 4-hydroxy-3-methoxybenzaldehyde 2 in an acid-catalyzed, Knoevenagel-like reaction at $75{ }^{\circ} \mathrm{C}$ for $2 \mathrm{~h}$ generated compound 3, which was reduced to form compound $\mathbf{4}$ in cold DCM using in situ generated $\mathrm{NaHB}(\mathrm{OAc})_{3}$ in an ice bath. The obtained material was recrystallized from hot ethyl acetate-hexane to obtain pure compound 4 (Scheme 1). The resultant product was white solid with a melting point at $130{ }^{\circ} \mathrm{C}$ and percentage yield of $63 \%$. The structure of compound $\mathbf{4}$ was confirmed based on elemental analysis and spectroscopy data. The IR spectrum of $\mathbf{4}$ indicated the presence of a hydroxyl group stretching vibration at $3518 \mathrm{~cm}^{-1}$. In addition, signals appeared at 2874, 1793, and $1755 \mathrm{~cm}^{-1}$, which were attributed to aliphatic $\mathrm{H}$ and carbonyl groups, respectively. The ${ }^{1} \mathrm{H}-\mathrm{NMR}$ spectrum of 4 showed a characteristic signal at $\delta=1.72 \mathrm{ppm}$ corresponding to the methyl protons; another signal, resonating at $\delta=3.85 \mathrm{ppm}$, was attributed to the methoxy proton. The aromatic protons resonated as a multiplet between $\delta=6.68$ and $6.85 \mathrm{ppm}$ with an integration value of three protons. The reduction of the ethylenic bond of compound 3 was characterized by the appearance of the new bands at $\delta=3.42$ and $3.66 \mathrm{ppm}$, corresponding to the $\mathrm{CH}_{2}$ and $\mathrm{CH}$ protons, respectively. The hydroxyl group appeared at $\delta=5.53 \mathrm{ppm}$ due to the exchange with $\mathrm{D}_{2} \mathrm{O}$. The ${ }^{13} \mathrm{C}$-NMR spectrum of compound $\mathbf{4}$ showed two new signals at $\delta=31.1$ and $46.3 \mathrm{ppm}$, which were assigned to the $\mathbf{C H}$ and $\mathbf{C H}_{2}$ carbons, while the signals at $\delta=146.2$,
144.7, 128.8, 122.5, 114.3, and $112.6 \mathrm{ppm}$ were caused by the aromatic carbons. The signal at $\delta=165.5 \mathrm{ppm}$ was assigned to the two carbonyl carbons.

Knoevenagel-condensations [9] are used to access carboxylic acids from a malonic acid and an appropriate aldehyde. 3-(4-Hydroxy-3-methoxyphenyl)propanoic acid 7 was synthesized by condensation of 4-hydroxy-3methoxybenzaldehyde $\mathbf{1}$ with malonic acid $\mathbf{5}$ to generate (E)-3-(4-hydroxy-3-methoxyphenyl)acrylic acid 6 followed by hydrogenation in the presence of $\mathrm{Pd} / \mathrm{C}$ to give compound 7 with a yield of $95 \%$ yield. This compound was synthesized and characterized by the reduction of olefinic compound 6 and the appearance of two triplet bands in its ${ }^{1} \mathrm{HNMR}$ spectrum at $\delta=2.90$ and $2.70 \mathrm{ppm}$ with the coupling constant $J=7.8 \mathrm{~Hz}$ respectively. In the ${ }^{13} \mathrm{CNMR}$ spectrum, the two new carbons bands, representing two $\underline{\mathrm{CH}}_{2}$, were detected at $\delta=36.0$ and 30.3 $\mathrm{ppm}$. The reaction of compound 7 with one equivalent of 1,1'carbonyldiimidazole in refluxing dry THF led to the formation of the corresponding $\mathrm{N}$-acylpiperdine compound 8 (Scheme 2), which was characterized by NMR spectroscopy, FTIR, and elemental analysis. The IR spectral data of compound $\mathbf{8}$ showed sharp bands at 1749 and $3392 \mathrm{~cm}^{-1}$, indicating the presence of $\mathrm{C}=\mathrm{O}$ and $\mathrm{OH}$ groups. The structure of $\mathbf{8}$ was also confirmed by the ${ }^{1} \mathrm{H}-\mathrm{NMR}$ spectral data, which showed a characteristic signal that resonated at $\delta=3.31-3.35 \mathrm{ppm}$ and 1.36-1.53, attributed to the 10 protons of piperidine. The ${ }^{13} \mathrm{C}$-NMR spectrum showed new signals resonating at $\delta=24.5$, 26.5 and $46.3 \mathrm{ppm}$, corresponding to the piperidine carbons.

The synthesis of chalcones is well established and is based on the Claisen condensation of substituted benzaldehydes and acetophenones, and is achieved under either basic [10] or acid [11] condition. Confirming primary literature research [12], because of the presence of the phenolic substituent, the acid catalysis showed to be more appreciate in most of the cases and thus the procedure was used for the prepared of the 4-hydroxy compound 10 (Scheme 3). The structure of the compound 10 was established by spectral analysis. The FTIR spectrum of compound $\mathbf{1 0}$ showed characteristic absorption bands at 3430, 1651, and $1563 \mathrm{~cm}^{-1}$,

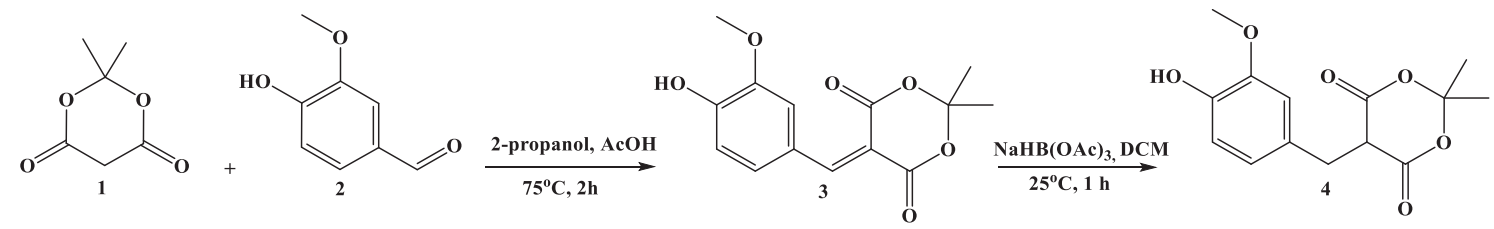

Scheme 1 The synthetic route to target compound 4 


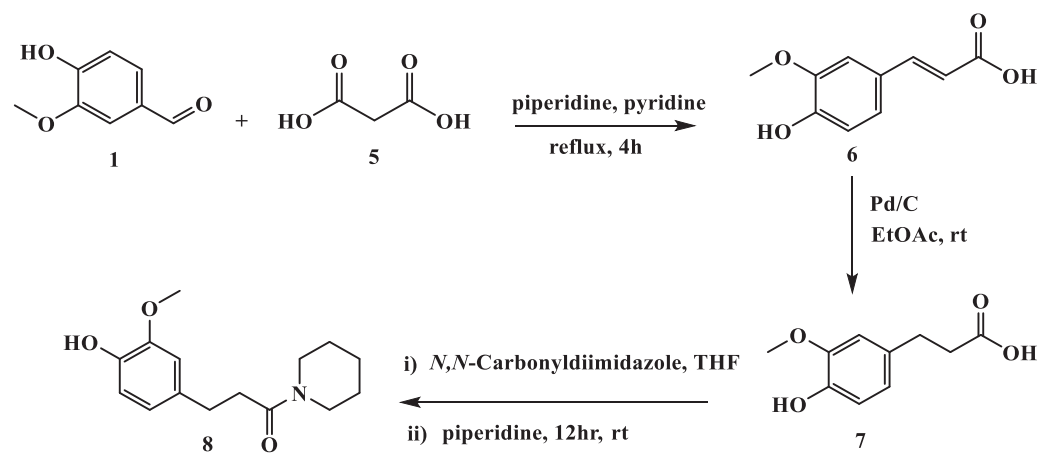

Scheme 2 The synthetic route to target compound 8<smiles>COc1cc(/C=C2\CCPCC\C2=C/c2ccc(O)c(OC)c2)ccc1O</smiles>
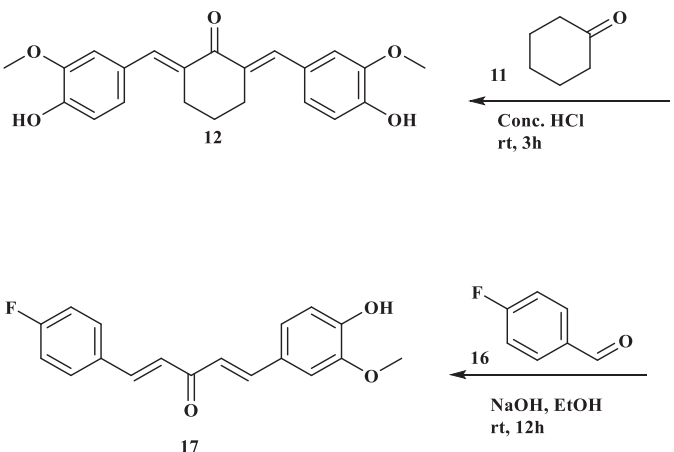<smiles>COc1cc(/C=C/C(C)=O)ccc1O</smiles>

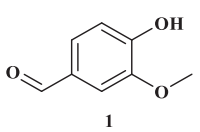

1

Acetone $\mathrm{NaOH}($ aq.)

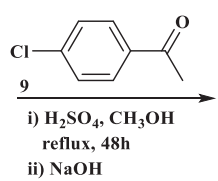<smiles>COc1cc(/C=C/C(=O)c2ccc(Cl)cc2)ccc1O</smiles>

ii) $\mathrm{NaOH}$
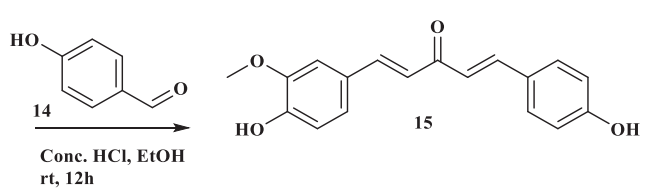

Scheme 3 The synthetic route to target compounds 10, 12, 15 and 17

corresponding to the $-\mathrm{OH}, \mathrm{C}=\mathrm{O}$, and $\mathrm{C}=\mathrm{C}$ functional groups. The ${ }^{1} \mathrm{H}$-NMR spectrum showed the presence of a broad singlet at $\delta=10.31 \mathrm{ppm}$ attributed to phenolic $\mathrm{OH}$ proton. Multiplet bands at $\delta=7.52-7.50 \mathrm{ppm}$ and 7.77-7.79 ppm were assigned to aromatic protons; a doublet $(J=15 \mathrm{~Hz})$ at $\delta=6.14 \mathrm{ppm}$ was characteristic for the olefinic proton $\mathrm{COCH}=\mathrm{CH}$, and another doublet $(J=15 \mathrm{~Hz})$ at $\delta=7.57 \mathrm{ppm}$ was characteristic for the second olefinic $\mathrm{COCH}=\mathrm{CH}$. The methyl protons appeared as a singlet in the $\delta=3.67 \mathrm{ppm}$. Compound 12, another mono-carbonyl derivative of curcumin was prepared from available 4-hydroxy-3-methoxybenzaldehyde $\mathbf{1}$ and cyclohexanone $\mathbf{1 1}$ in ethanol via enamine intermediate in the presence of acidic medium. Compound $\mathbf{1 2}$ was obtained in a $70 \%$ yield (Scheme 3). The FTIR spectrum of compound 12 recognized two absorption bands at 3368 and $1639 \mathrm{~cm}^{-1}$, distinctive for $\mathrm{OH}$ and $\mathrm{C}=\mathrm{O}$ groups. The ${ }^{1} \mathrm{H}$ NMR spectrum had two signals at $\delta=7.74 \mathrm{ppm}$ that coordinated the vinylic protons of benzylidenes. The ${ }^{13} \mathrm{C}$ NMR spectrum of compound 12 showed that the carbonyl carbon was specified downfield at $\delta=190.1 \mathrm{ppm}$.

The unsymmetrical analogs of curcumin, compounds 15 and 17, were characterized by the presence of a short but entirely conjugated unsaturated ketone chain. Both compounds were prepared from (E)-4-(4-hydroxy-3methoxyphenyl)but-3-en-2-one 13. Compound 13 was obtained from vanillin and acetone in aqueous sodium hydroxide in a mixture that was stirred at room temperature for $12 \mathrm{~h}$. The reaction mixture was diluted with ice water and neutralized with $\mathrm{HCl}$ to obtain a yellow solid $\mathbf{1 3}$ with a $70 \%$ yield. Compound $\mathbf{1 3}$ was used to prepare the unsymmetrical diarylpentanoid analogues $\mathbf{1 5}$ and 17. The targeted diarylpentanoids were synthesized to assess the effect of the substitution on the aromatic rings and to explore the effect of different aryl groups upon antioxidant activity. The characterization and spectroscopic date of compounds $\mathbf{1 5}$ and $\mathbf{1 7}$ were investigated. Compounds $\mathbf{1 5}$ and $\mathbf{1 7}$ were produced by reacting compound $\mathbf{1 3}$ with different aldehydes, having electron donating and electron withdrawing moieties. It was completely characterized by NMR. For compound 15, one double bond and aromatic moiety was added, and ${ }^{1} \mathrm{H}$ NMR had two more doublets for $-\mathrm{CH}=\mathrm{CH}$ - with a coupling constant of approximately $15 \mathrm{~Hz}$, which is characteristic of an $\mathrm{H}-\mathrm{H}$ trans-coupling system at $\delta=7.65$ and $7.34 \mathrm{ppm}$. The aromatic multiplet signals appeared at $\delta=7.60-7.62$ ppm, 7.08-7.19 ppm, and 6.81-6.82 ppm, which integrated to seven protons.

\section{Antioxidant Activity}

Free radical scavenging capabilities were determined for all compounds by the DPPH and ABTS assays. DPPH is 
a very stable free radical, which is reduced by accepting hydrogen from a hydrogen donor compound. Reduction of DPPH results in the disappearance of its violet color, indicating the presence of free radical scavenging compounds in the reaction mixture. Similarly, the ABTS radical cation can be produced in aqueous solution. The blue color of the ABTS radical absorbs light at $734 \mathrm{~nm}$ and can be used to monitor the radical scavenging capacity of a substance relative to the antioxidant potential of this substance.

The DPPH and ABTS reducing capabilities of all synthetic compounds were evaluated by determining their $\mathrm{IC}_{50}$ values. The antioxidant activity analysis of the six synthetic compounds indicated a strong reducing activity. The $\mathrm{IC}_{50}$ values of all compounds obtained in the DPPH, ABTS, and ORAC assays are presented in Table 1 . The $\mathrm{IC}_{50}$ value corresponds to the concentration of a sample, which has ability to scavenge $50 \%$ of the free radicals present in the reaction mixture. Low $\mathrm{IC}_{50}$ values indicate a high antioxidant activity of the sample compound.

As shown in the Table 1 and Figure 2, all compounds had free radical scavenging activity in the DPPH assay. The $\mathrm{IC}_{50}$ values in the $\mathrm{DPPH}$ assays were in the range of 13.3-40.6 $\mu \mathrm{M} \mathrm{DPPH}$. Compound 4, which has one - $\mathrm{OH}$ group, showed highest antioxidant activity $(13.3 \mu \mathrm{M})$. Compound $\mathbf{1 5}$ with two - $\mathrm{OH}$ groups had the lowest antioxidant activity $(40.6 \mu \mathrm{M})$. The difference in free radical scavenging activity among the six compounds could be related to the presence of different characteristic groups at the end of their carbon side chain. The compounds having the least polar groups attached with the 2-methoxyphenol moiety of derived compounds, (compound $\mathbf{4}$ and $\mathbf{8}$ ), had a higher free radical scavenging activity (13.3 $\mu \mathrm{M}$ and $15.1 \mu \mathrm{M}$, respectively) in the DPPH assay, compared with the compounds having more hydrophilic end groups (compounds 12 and 15; IC $40.1 \mu \mathrm{M}$ and $40.6 \mu \mathrm{M}$, respectively) (Table 1). High antioxidant activity by ferulic acid derivatives bearing non-polar groups in the side carbon chain has been reported already by Nenadis et al. [13].

An interesting structural modification with a positive effect on the reducing properties of our synthetic compounds was the introduction of halogen atoms, $\mathrm{Cl}$ and $\mathrm{F}$, at the end of the side chain of the compounds. The substitution of $\mathrm{Cl}$ and $\mathrm{F}$ doubled the free radical scavenging activity of compounds $10(18.1 \mu \mathrm{M})$ and $\mathbf{1 7}$ $(19.3 \mu \mathrm{M})$, compared to compounds $12(40.1 \mu \mathrm{M})$ and $15(40.6 \mu \mathrm{M})$ with an -OH group at the end of the side chain. Our results confirm the finding by Puskullu et al. [14]. Their study also indicated that according to the structure activity relationship, halogenated derivatives have a better antioxidant activity. The $\mathrm{IC}_{50}$ of ferulic acid

Table 1 Antioxidant activity of phenolic acid derivatives using the DPPH, ABTS, and ORAC assays

\begin{tabular}{|c|c|c|c|c|}
\hline Compound & Structure & $I C_{50}(\mu \mathrm{M}) \mathrm{DPPH}$ & ABTS ( $\mu M$ TE) & ORAC $(\mu M$ TE $)$ \\
\hline 4 & & $13.31 \pm 1.5$ & $183.3 \pm 7.7$ & $242.0 \pm 1.9$ \\
\hline 8 & & $15.11 \pm 1.7$ & $141.8 \pm 32.3$ & $276.2 \pm 15.9$ \\
\hline 10 & & $18.14 \pm 1.6$ & $165.9 \pm 24.4$ & $299.8 \pm 4.4$ \\
\hline 12 & & $40.18 \pm 2.4$ & $231.1 \pm 10.4$ & $280.7 \pm 6.3$ \\
\hline 15 & & $40.6 \pm 2.8$ & $159.8 \pm 34.5$ & $302.3 \pm 3.0$ \\
\hline 17 & & $19.3 \pm 1.2$ & $156.7 \pm 28.5$ & $310.3 \pm 4.5$ \\
\hline
\end{tabular}




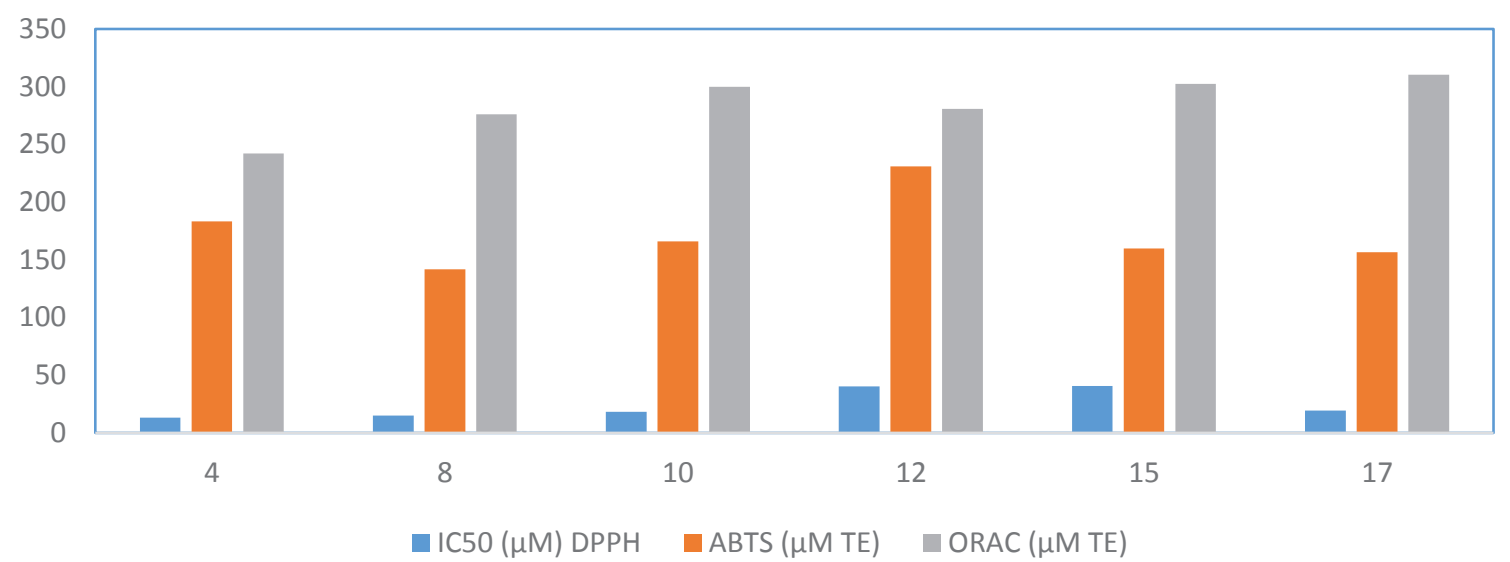

Figure 2 Comparison of antioxidant activity of phenolic acid derivatives using the DPPH, ABTS, and ORAC assays

has been reported by Aleksandra et al.[15]; the DPPH value is $44.6 \mu \mathrm{mol} / \mathrm{L}$. Therefore, all compounds had a higher antioxidant activity than ferulic acid in the DPPH assay. Moreover, the comparison of antioxidant activities of all compounds with the standard antioxidant molecules like ascorbic acid and Trolox revealed that all compounds have lower $\mathrm{IC}_{50}$ vales than $\mathrm{IC}_{50}$ values of ascorbic acid $(41.25 \mu \mathrm{g} / \mathrm{ml})$ and Trolox $(63.69 \mu \mathrm{g} / \mathrm{mL})$ in DPPH assay, which have been reported by Matuszewska et al. [16].

The measurements of the ABTS and the ORAC assay showed lower antioxidant activities of compounds, compared to DPPH assay results. The $\mathrm{IC}_{50}$ values by the ABTS method ranged from 134.5-231.1 $\mu \mathrm{M}$ TE (Table 1). This difference between DPPH and ABTS radical scavenging activities can be attributed to the solubility of a compound in a specific reaction medium. The DPPH assays are normally conducted in $50 \%$ ethanol medium, and the ABTS assays are conducted in aqueous solution. Therefore, the compounds, which are less soluble in water have less activity in the ABTS assay than in the DPPH assay. As shown in Table 1, the DPPH assay results showed that compound $\mathbf{1 2}$ had the lowest antioxidant activity (231.1 $\mu \mathrm{M}$ TE) in the ABTS assay. Overall, despite the solubility issues in the DPPH and ABTS assay reaction mixtures, the antioxidant activities of the compounds were similar in these two assays, suggesting that the synthesized compounds possessed reliable, significant antioxidant properties.

In addition to the DPPH and ABTS free radical scavenging activities, the antioxidant activities of all six compounds were tested with the ORAC assay. The assay indicates the oxidative degradation of a fluorescent compound after being mixed with a free radical producer. The presence of the antioxidant protects the fluorescent molecule from degradation. Out of the six test compounds, the maximum antioxidant activity was observed with compound 4 ( $\mathrm{IC}_{50} 242 \mu \mathrm{M} \mathrm{TE}$ ), followed by compound 8 ( IC $_{50} 276.2 \mu \mathrm{M}$ TE). A similar observation was made with the other two assays. However, instead of compound 12 and 15, which showed the lowest activity in the DPPH and ABTS assays, compound $\mathbf{1 7}$ showed the lowest antioxidant activity in the ORAC assay. The varying trends in the antioxidant activity by different assays could be explained with the effect of the reaction medium used in the different assays. Different compounds could have different hydrogen abstraction mechanisms depending on the reaction medium.

\section{Mechanism Suggested for Hydrogen Abstraction from the Antioxidants}

Free radicals $\left(\mathrm{ROO}^{\circ}\right)$ react with phenols $(\mathrm{ArOH})$ via the following prominent mechanisms

(i) Hydrogen atom transfer (HAT) is the abstraction of the hydrogen atom of ArOH by free radicals where the bond dissociation energy of $\mathrm{O}-\mathrm{H}$ bond controls the rate of reaction. The HAT is dominant in a polar solvents and non-protic polar solvents [17]. These solvents do not support ionisation of $\mathrm{ArOH}$ thus the release of hydrogen as free radical from $\mathrm{ArOH}$ is slow therefore decreasing the rate of $\mathrm{ArOH}$-free radical reactions. Hydrogen atom transfer (HAT) being very slow requires a higher concentration of the antioxidant to get 50\% inhibition of free radicals, which would result in higher $\mathrm{IC}_{50}$ value. Antioxidant action reduced with an increase in proportion of water. The consequence can elucidate in terms of Bond Dissociation Energy 
(BDE) of phenol [18]. Solvents such as alcohols and water are able to both accept and donate hydrogen bonds and therefore could either improve or reduce the Bond Dissociation Energy (BDE) of phenol. Water is a better donor but a poorer acceptor of hydrogen bonds than alcohols and hence should be able of better solvating the phenoxyl radical and solvating the parent phenol less or ethanol solvate curcuminoids rather than water. By increasing the percentage of water, the degree of solvation decreases and the phenoxide ion production decreases and this will affect the antioxidant activity. The buffer used as medium in both methods ABTS and ORAC, thereby decreasing the concentration of phenoxide ion formed from reacting antioxidants. Therefore, quenching of free radical produced requires a higher concentration of antioxidant samples. IC $_{50}$ values in ABTS and ORAC method are higher owing to the reduction of phenoxide ion in the lack of medium as shown in Scheme 4.

(ii) The sequential proton loss electro transfer mechanism (SPLET) [17] operates predominantly in polar protic solvents like methanol and ethanol.

The kind of solvent and polarity might affect the process of single electron transfer and the hydrogen atom transfer, which are main features in the measurement of antioxidant activity. In DPPH assay method ethanol was used as a solvent, the antioxidants showed the maximum reducing ability. This behavior was attributed to polarity of ethanol establishing intermolecular hydrogen bonding amongst the solvent and thus hindering $\mathrm{ArOH}$ (substrate) and $\mathrm{S}$ (solvent) interaction as shown in Scheme 5.

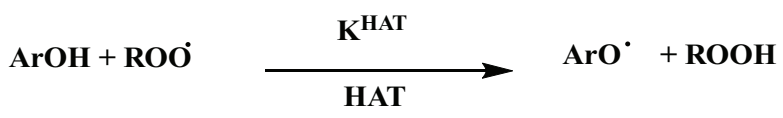

Scheme 4 HAT in a polar and non-protic solvents

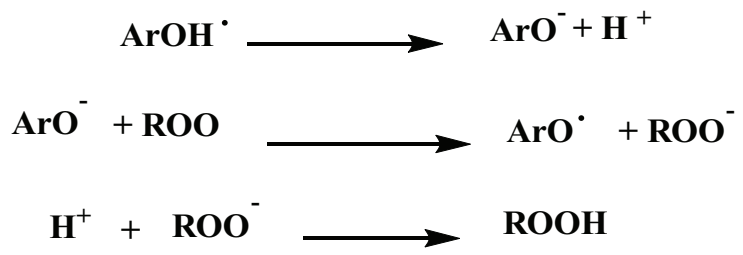

Scheme 5 Proton Loss Electron Transfer (SPLET) in protic solvents
Therefore, substrate to solvent equilibrium do not occur in ethanol, allowing the ionisation of substrate ( $\mathrm{ArOH})$ depending on the properties of the solvent such as its relative permittivity (dielectric constant, $\varepsilon_{\mathrm{r}}$ ), molecular property, its relative capability to solvate stabilising anions ( $\left.\mathrm{ArO}^{-}\right)$, as measured by Swain et al's A value [17]. Ethanol as a solvent having high dielectric constant equal to 25 supports ionisation, ArOH loses proton to form stable phenoxide ion at fast rate. Therefore, quenching of DPPH occurs at low concentration of ArOH, obtaining a very low $\mathrm{IC}_{50}$ value. Hence resolved that the ionisation affinity of solvent medium support the SPLET or relief of proton as Scheme 6.

\section{Structure activity relationship in DPPH}

In DPPH reaction the structure activity relationships with respect to the solvent ethanol is analysed. The influence and effect of ethanol on antioxidant capacity is well defined as studied by various solvent effect kinetics studies $[17,18]$. As for the ABTS and ORAC assay the reacting medium is a buffer solution and hence difficult to interpret the quenching ability of antioxidants synthesized in terms of two reactants. Compounds of which has half curcumin structure is having an $\mathrm{IC}_{50}$ value comparable to curcumin of $17.88 \mu \mathrm{M}$ [19]. In Group 1 the compounds 4 and 8 exhibited excellent antioxidant activity using $\mathrm{DPPH}$ method with $\mathrm{IC}_{50}$ values $13.31 \pm 1.5 \mu \mathrm{M}$ and $15.11 \pm$ $1.7 \mu \mathrm{M}$ respectively as compared with curcumin $(17.88 \mu \mathrm{M})$, which could be attributed to the heterocyclic ring centers and phenolic ring in the structures which enhances the antioxidant activity [20]. In Group 2 compounds 10 (18.14 $1.6 \mu \mathrm{M})$ and $17(19.3 \pm 1.2 \mu \mathrm{M})$ members have comparable $\mathrm{IC}_{50}$ values, contributing part will be half curcumin and the halogen substituted in the second benzene ring[14]. Finally, Group 3 represented by compounds $\mathbf{1 2}$ and $\mathbf{1 5}$ showed the lower activities with $\mathrm{IC}_{50}$ values $40.18 \pm 2.4 \mu \mathrm{M}$ and $40.6 \pm 2.8 \mu \mathrm{M}$ and this may be attributed to the steric effects offered by the extended ring structure (Table 2 and Figure 3). A brief investigation of the structure-activity relationship (SAR) revealed that halogen substitution and the presence of heteroring contributed to better antioxidant activity.

In curcumin, the phenolic group is accepted as the major reaction site where the electron capture takes place

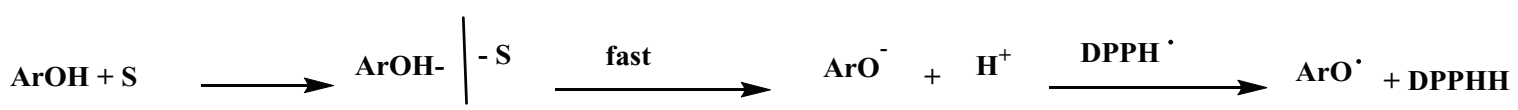

Scheme 6 Anomalous behavior of phenolic antioxidants in ethanol 
either as $\mathrm{ArO}$ or as $\mathrm{ArO} ;$; the single electron moves towards the di-ketone moiety, giving free radical i, ii, and iii (Figure 4). The product analysis study also confirms that diketo moiety contribution is very less towards the antioxidant property [21]. However, experimental evidence indicates the relative importance of different mechanisms in different solvents and contributing centers, accounting for the antioxidant activity of curcumin and other antioxidants. The solvent attributes for the difference in $\mathrm{IC}_{50}$ values got by DPPH, ABTS, and ORAC method.

\section{Conclusions}

In summary, a series of compounds containing the 2-methoxyphenol moiety were successfully synthesized with a good yield of 48-95\%. The characterisation of compounds were identified using different spectral studies. The synthesized compounds exhibited a wideranging of possibly promising antioxidant activities. All compounds displayed antioxidant activities using the DPPH, ABTS, and ORAC method. Compounds $\mathbf{8}$ and $\mathbf{1 3}$ showed the highest antioxidant activity with

Table $2 \quad \mathrm{IC}_{50}$ value of DPPH $(\mu \mathrm{M})$ of the synthesized compounds

Group.no Compound<smiles>COc1ccccc1[O-]</smiles><smiles>C1CCOCC1</smiles><smiles>C[N+]1CCCCC1</smiles>

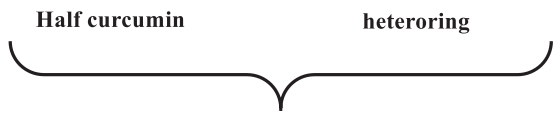

Group 1
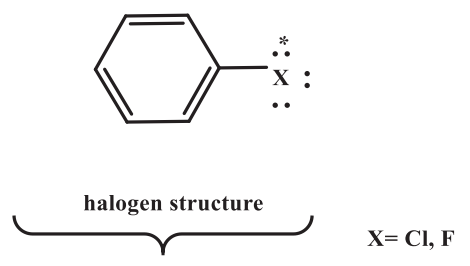

Group 2

* Reactive center

Figure 3 Free radicals centers of the synthesized compounds<smiles>COc1cc(/C=C/C(=O)/C=C([O])/C=C/c2ccc(/C=C/C(=O)CC(=O)/C=C/c3ccc(O)c(OC)c3)c(OC)c2)ccc1O</smiles>

Figure 4 Free radical centers of curcumin 
the ABTS method, whereas compound $\mathbf{4}$ had the highest antioxidant activity in both the DPPH and ORAC assays. Compounds $\mathbf{1 0}$ and $\mathbf{1 7}$ showed antioxidant activity using different methods. This was due to the fact that all these compounds could generate free radical centers, which were stabilized by the hyper-conjugative effect and the electron-withdrawing groups present in the structures. The mechanism of oxidation of phenolic compounds in a reaction with DPPH is considered as sequential protonloss electron transfer (SPLET) based mechanism in protic solvent like EtOH. All test phenolic compounds showed a higher antioxidant activity by DPPH assay because this assay was done in EtOH as compared to other assays, ABTS and ORAC, which were performed in aqueous solution. Both, ABTS and ORAC, are HAT mechanism-based assays involve donation of $\mathrm{H}$-atom in quenching of free radicals. The major factor contributes in scavenging of free radical in HAT mechanism is bond dissociation energy (BDE) of $\mathrm{O}-\mathrm{H}$ bond that is related to the stability of the phenoxyl radical (ArO).

Acknowledgments: The authors are grateful to the Merck Company for the providing with chemicals needed for accomplishing this task.

Conflicts of Interest: The authors declare no competing interests.

\section{References}

[1] Halliwell B, Gutteridge JM; In Free Radicals in Biology and Medicine. Halliwell, B., Gutteridge, J. M. C., Eds., second ed.; Oxford University Press, Clarendon: Oxford, 1989, pp.1-20.

[2] Braughler JM, Duncan LA, Chase RL. The involvement of iron in lipid peroxidation. Importance of ferric to ferrous ratios in initiation. J Biol Chem. 1986;261:10282-9.

[3] Beal MF. Aging energy and oxidative stress in neurodegenerative diseases. Ann Neurol. 1995;38:357-66.

[4] Altemimi A, Lakhssassi N, Baharlouei A, Watson D, Lightfoot D. Phytochemicals: Extraction, Isolation, and Identification of Bioactive Compounds from Plant Extracts. Plants. 2017;6:42.

[5] Kim JY, Tang NX, Yenari MA. Apocynin in the Treatment of Ischemic Stroke. Open Drug Discov J. 2010;2:187-9.

[6] Fujisawa S, Atsumi T, Kadoma Y, Sakagami H. Antioxidant and prooxidant action of eugenol-related compounds and their cytotoxicity. Toxicology. 2002;177:39-54.
[7] Zhihong C, Jeffrey M, Liangli LY. High-Throughput Relative DPPH Radical Scavenging Capacity Assay. J Agric Food Chem. 2006;54:7429-36.

[8] Koleva L, Angelova S, Dettori M, Fabbri D, Delogu G, Kancheva V. Antioxidant activity of selected 0 -methoxyphenols and biphenols: theoretical and experimental studies. Izv Him. 2018;50.

[9] Jack VS, Luiz AC, Dennis M, Jan M. The green Knoevenagel condensation: solvent-free condensation of benzaldehydes. Green Chem Lett Rev. 2017;10(4):404-11.

[10] Naveen CT, Pallvi S. Synthesis and Antimicrobial Activity of Chalcones. J Chem Pharm Res. 2016;8(5):610-3.

[11] Ramalho SD, Bernades A, Demetrius G, Noda-Perez C, Vieira PC, Santos CY, et al. Synthetic Chalcone Derivatives as Inhibitors of Cathepsins K and B, and Their Cytotoxic Evaluation. Chem Biodivers. 2013;10:1999-2006.

[12] Carapina Da Silva C, Silveira Pacheco B, Coelho de Freitas S, Moraes Berneira L, Ziemann dos Santos MA, Pizzuti L (Trindade M, editor). C. M., Pereira de Pereira in Increased biodiesel efficiency. Alternatives for production, stabilization, characterization and use of coproduct. Cham: Springer; 2018. pp. 81-110.

[13] Nikolaos N, Susanne B, Evangelos GB, Maria T. An experimental approach to structure-activity relationships of caffeic and dihydrocaffeic acids and related monophenols. J Am Oil Chem Soc. 2003;80(5):451-8.

[14] Nilima K, Dilshad N, Biplab KD, Uttom K, Abu Shara SR. Synthesis and Antioxidant Activity of Some Novel Benzimidazole Derivatives, Dhaka Univ. J Pharm Sci. 2018;16:245.

[15] Aleksandra S, Dobrochna R, Marek PK. Synthesis of novel octyl sinapate to enhance antioxidant capacity of rapeseedlinseed oil mixture. J Sci Food Agric. 2018;98(4):1625-31.

[16] Anna M, Magdalena J, Dawid S, Tomasz C, tukasz M. Anticancer, antioxidant, and antibacterial activities of low molecular weight bioactive subfractions isolated from cultures of wood degrading fungus Cerrena unicolor. PLoS One. 2018;13(6):197044.

[17] Nielsen MF, Ingold KU. Kinetic Solvent Effects on Proton and Hydrogen Atom Transfers from Phenols. Similarities and Differences. J Am Chem Soc. 2006;128(4):1172-82.

[18] Guerra M, Amorati R, Pedulli GF. Water Effect on the O-H Dissociation Enthalpy of Para-Substituted Phenols: a DFT Study. J Org Chem. 2004;69:5460-7.

[19] Priya RS. B.S.; Daisy, J; Mohanan, P.V, Reactive Centers of Curcumin and the Possible Role of Metal Complexes of Curcumin as Antioxidants. Universal Journal of Physics and Application. 2015;3(1):16.

[20] Kenichi YK, Hirotomo O, Takayuki S. Antioxidative Activity of Heterocyclic Compounds Found in Coffee Volatiles Produced by Maillard Reaction. J Agric Food Chem. 2002;50:5480-4.

[21] Masuda T, Hidaka K, Shinohara A, Maekawa T, Takeda Y, Yamaguchi H. Chemical Studies on Antioxidant Mechanism of Curcuminoid: Analysis of Radical Reaction Products from Curcumin. J Agric Food Chem. 1999;47(1):71-7. 